\title{
Proteome analysis of human substantia nigra in Parkinson's disease
}

\author{
Manuela Basso ${ }^{1 *}$, Sabrina Giraudo ${ }^{*}$, Davide Corpillo ${ }^{3}$, Bruno Bergamasco ${ }^{2,4}$, \\ Leonardo Lopiano ${ }^{2}$ and Mauro Fasano ${ }^{1}$ \\ ${ }^{1}$ Department of Structural and Functional Biology, and Center of Neuroscience, \\ University of Insubria, Busto Arsizio, Italy \\ ${ }^{2}$ Department of Neuroscience, University of Torino, Torino, Italy \\ ${ }^{3}$ Bioindustry Park Canavese, Colleretto Giacosa, Italy \\ ${ }^{4}$ Salvatore Maugeri Foundation, Pavia, Italy
}

Protein expression has been compared in human substantia nigra specimens from Parkinson's disease (PD) patients and from controls, and 44 proteins expressed in this midbrain region were identified by peptide mass fingerprinting. Among them, nine showed changes in their abundance. $L$ and $M$ neurofilament chains are less abundant in PD specimens, whereas peroxiredoxin II, mitochondrial complex III, ATP synthase D chain, complexin I, profilin, L-type calcium channel $\delta$-subunit, and fatty-acid binding protein are significantly more present in PD samples than in controls. Besides the consolidated view of oxidative stress involvement in PD pathogenesis, suggested by overexpression of mitochondrial and reactive oxygen species (ROS)-scavenging proteins, these results indicate a possible potentiation mechanism of afferent signals to substantia nigra following degeneration of dopaminergic neurons.

Keywords: Excitotoxicity / Mitochondrial impairment / Oxidative stress / Parkinson's disease / Protein expression

Received: February 24, 2004; revised: April 6, 2004; accepted: April 13, 2004

\section{Introduction}

Parkinson's disease (PD) is the second most common neurodegenerative disorder after Alzheimer's disease (AD), with a prevalence of about $2 \%$ among people over the age of 65 years [1, 2]. The characteristic motor symptoms are associated with the depletion of dopaminergic melanin-containing neurons in the substantia nigra pars compacta (SNpc) and a consequent loss of dopamine in the striatum [1]. Another important pathological feature is the presence, especially in SNpc neurons, of eosinophilic cytoplasmic inclusion bodies (Lewy bodies, LB) $[1,3,4]$. LB show a strong staining with anti- $\alpha$-synuclein antibodies [5], a presynaptic protein involved in a familial form of the disease $[6,7]$, present as the main

Correspondence: Mauro Fasano, Center of Neuroscience, University of Insubria, via Alberto da Giussano 12, I-21052 Busto Arsizio (VA), Italy

E-mail: mauro.fasano@uninsubria.it

Fax: $+39-0331-339459$

Abbreviations: AD, Alzheimer's disease; LB, Lewy bodies; PD, Parkinson's disease; ROS, reactive oxygen species; SN, substantia nigra filamentous component [8-10]. In vitro studies showed that both mutated and wild-type $\alpha$-synucleins do form fibrils similar to those of LB; moreover, $\alpha$-synuclein molecules carrying either one of the two point mutations observed in the familial PD will aggregate faster than the wild-type protein [11-13]. Recently, the effects of changes in the $\alpha$-synuclein sequence on the enhanced susceptibility of cells to reactive oxygen species (ROS) have been reported [14-17], providing a pathogenic link between $\alpha$-synuclein anomalies and a putative role of ROS in the cell death mechanisms in PD [18-21].

Substantia nigra $(\mathrm{SN})$ is a preferential candidate to oxidative damage, since it contains oxidizable dopamine, neuromelanin, polyunsaturated fatty acids, iron, and relatively low antioxidant complement [21]. In this context, mitochondria are involved in a number of cellular reactions that potentially lead to the formation of ROS, like superoxide anions, hydroxyl radicals, and hydrogen peroxide. Complexes I and III in particular are associated with superoxide production, and the inhibition of these complexes results in increased free radical production. Mito-

* These authors contributed equally. 
chondria contain antioxidant defence systems, such as glutathione, catalase, and superoxide dismutase, to carefully balance free radical production and detoxification. Oxidative stress is believed to be important in the ageing process and details of how ROS are produced from various intra- and extracellular sources as well as the cellular defence mechanisms and responses to oxidative stress have recently been extensively reviewed [22, 23].

Nowadays, the occurrence of a tight association of proteins to form insoluble supramolecular aggregates is considered to be the basis of a number of neurological diseases, both familial and sporadic. Self-aggregation of $\alpha$-synuclein, wrong folding of the prion protein, defective cleavage of the amyloid $\beta$-peptide and hyperphosphorylation of the tau protein all lead to changes in the dynamics of cytosolic proteins and eventually the formation of macroscopic aggregates in PD, spongiform encephalopathy, and AD, respectively $[8,24]$. An analysis of the water dynamics in ex vivo specimens of SNpc has shown a differential deposition of cytosolic proteins with respect to age-matched controls [25]. It has recently been proposed that misfolded $\alpha$-synuclein could form channels in dopamine storage vesicles, thus contributing to the formation of cytoplasmic ROS due to dopamine oxidative catabolism [26].

In the present work, we describe a proteomic analysis of $\mathrm{SN}$ tissue in order to evaluate changes in the expression level of proteins that could provide information on the pathogenetic mechanism and on the pathways herein involved. To this purpose, we performed a two-dimensional electrophoretic (2-DE) separation of proteins extracted from ex vivo specimens from controls and PD patients. Forty-four proteins have been identified by peptide mass fingerprinting and their expression levels have been compared and statistically evaluated. Among them, nine proteins showed differential expression in PD patients respect to age-matched controls.

\section{Materials and methods}

\subsection{Chemicals}

Immobilized pH gradient (IPG) strips, IPG buffer, acrylamide, and Coomassie Brilliant Blue R-250 were purchased from Amersham Biosciences (Uppsala, Sweden). Modified trypsin was from Promega (Madison, WI, USA). ZipTip $_{\mathrm{c} 18}$ were from Millipore (Bedford, MA, USA). The protease inhibitor mix (from Sigma Chemical, St. Louis, $\mathrm{MO}$, USA) contained 4-(2-aminoethyl)benzenesulfonyl fluoride (AEBSF), pepstatin A, trans-epoxysuccinyl-L-leucylamido(4-guanidino)butane (E-64), bestatin, leupeptin, and aprotinin, and was used according to manufacturer's instructions. All other chemicals were obtained from Sigma Chemical and used without further purification.

\subsection{Tissues}

Specimens of human $\mathrm{SN}$ from four patients having known PD history (sex 3 M, 1 F, aged $75 \pm 3$ years; deceased 13 \pm 2 years after diagnosis; postmortem delay $4 \mathrm{~h} 38 \mathrm{~min} \pm$ 26 min; brain weight $1156 \pm 94 \mathrm{~g}$ ) were provided by the Nederlandse Hersenbank (the Netherland's Brain Bank), Amsterdam. Each specimen was accompanied by histopathological report, showing depletion of pigmented dopaminergic neurons and the occurrence of extracellular neuromelanin granules as well as LB in surviving neurons. Four control specimens (sex $3 \mathrm{M}, 1 \mathrm{~F}$, aged $70 \pm 8$ years; postmortem delay $6 \mathrm{~h} 19 \mathrm{~min} \pm 1 \mathrm{~h} 11 \mathrm{~min}$; brain weight $1441 \pm 127 \mathrm{~g})$, not affected by neurodegenerative disorders, have been obtained from the same brain bank, also with histopathological report. SN have been excised from thawed autoptic specimens in order to refine the region of interest by cutting the surrounding unpigmented area using ceramic tools to avoid metal contamination of the samples. For less-pigmented PD tissues, a corresponding area has been removed. When present, blood clots have been removed before sample processing.

\subsection{Protein extraction}

Specimens (0.5-0.7 g) were homogenized (20 up-anddown strokes with a Teflon homogenizer followed by five passages through a 22-gauge needle) in $3 \mu \mathrm{L}$ lysis solution (7 m urea, $2 \mathrm{~m}$ thiourea, 4\% v/v CHAPS, $0.05 \mu \mathrm{L}$ protease inhibitor mix) per mg tissue. After centrifugation at $21000 \times g$ for $30 \mathrm{~min}$ at $20^{\circ} \mathrm{C}$ supernatants were recovered; protein content was estimated with the 2D-Quant kit (Amersham Biosciences).

\section{$2.42-D E$ and data analysis}

2-DE was performed according to Jacobs [27], with some modifications. Samples $(\sim 1 \mathrm{mg}$ for Coomassie staining, $\sim 100 \mu \mathrm{g}$ for silver staining) were diluted to $250 \mu \mathrm{L}$ with a buffer containing $7 \mathrm{~m}$ urea, $2 \mathrm{~m}$ thiourea, 4\% CHAPS, 0.5\% IPG buffer 3-10, 2 mM tributylphosphine, and traces of bromophenol blue and loaded onto $13 \mathrm{~cm}$ IPG DryStrips with a nonlinear $\mathrm{pH} 3-10$ gradient by in-gel rehydration (1 $\mathrm{h}$ at $0 \mathrm{~V}, 10 \mathrm{~h}$ at $30 \mathrm{~V}$ ). IEF was performed at $16^{\circ} \mathrm{C}$ on an IPGphor (Amersham Biosciences) according to the following schedule: $1 \mathrm{~h}$ at $200 \mathrm{~V}, 30 \mathrm{~min}$ of a linear gradient to $3500 \mathrm{~V}$, $3 \mathrm{~h}$ at $3500 \mathrm{~V}, 2.5 \mathrm{~h}$ of a linear gradient to $8000 \mathrm{~V}, 6 \mathrm{~h}$ at $8000 \mathrm{~V}$. Prior to SDS-PAGE, the IPG strips were equilibrated for $2 \times 30 \mathrm{~min}$ in $50 \mathrm{~mm}$ Tris- $\mathrm{HCl}, \mathrm{pH} 8.8,6 \mathrm{~m}$ urea, $30 \%$ glycerol, $2 \%$ SDS, and traces of bromophenol blue containing 1\% DTT for the first equilibration step and 2.5\% iodoacetamide for the second one. SDS-PAGE was performed using $12.5 \%$ T, 2.6\% C $1.5 \mathrm{~mm}$ thick separating polyacrylamide gels without stacking gel, using a Hoefer 
SE 600 system (Amersham Biosciences). The second dimension was carried out at $45 \mathrm{~mA} / \mathrm{gel}$ at $16^{\circ} \mathrm{C}$ and was terminated when the bromophenol dye front had migrated to the lower end of the gels. Carbamylated $\mathrm{p} /$ calibration markers (Amersham Biosciences) and molecular mass marker proteins (14-66 kDa from Sigma Chemical) were used for calibration of the molecular mass. The gels were stained either with Coomassie Brilliant Blue R-250 or according to Sinha's silver staining method [28]. After staining, gels were scanned with the ImageMaster Labscan V3.0 (Amersham Biosciences) and images were analyzed with ImageMaster 2D Elite V4.01 software package (Amersham Biosciences). Coomassie-stained spots were quantified on the basis of their relative volume (the spot volume divided by the total volume over the whole set of gel spots) and statistically analyzed according to the nonparametric Wilcoxon test. Relationships were considered statistically significant when $p<0.05$.

\subsection{Tryptic digestion of 2-DE gel spots}

Coomassie-stained spots were manually excised and destained overnight with $40 \%$ ethanol in $25 \mathrm{~mm}$ ammonium bicarbonate. Gel pieces were washed twice with $25 \mathrm{~mm}$ ammonium bicarbonate and desiccated three times with acetonitrile. Each piece was then reswollen in $25 \mathrm{~mm}$ ammonium bicarbonate containing $1.2 \mu \mathrm{g}$ of modified porcine trypsin and digestion proceeded overnight at $37^{\circ} \mathrm{C}$. Peptides were extracted by sonication in $25 \mathrm{~mm}$ ammonium bicarbonate and loaded on ZipTip $\mathrm{c} 18$.

\subsection{MALDI-TOF-MS}

Each peptide sample was eluted from ZipTip ${ }_{\mathrm{C} 18}$ with a saturated solution of $\alpha$-cyano-4-hydroxycinnamic acid in $70 \%$ acetonitrile and $0.2 \%$ TFA and $0.5 \mu \mathrm{L}$ was spotted directly on a MALDI target plate. MALDI mass spectra were acquired in the positive reflectron ion mode with delayed extraction on a Reflex III time of flight instrument (Bruker Daltonics, Bremen, Germany) equipped with a $337 \mathrm{~nm}$ nitrogen laser. Ion acceleration voltage was set to $20.00 \mathrm{kV}$, the reflector voltage was set to $23.00 \mathrm{kV}$ and the first extraction plate was set to $17.05 \mathrm{kV}$. Mass spectra were obtained by averaging 600 laser shots. Calibration of the spectra was performed internally by a two-points linear fit, using the autolysis products of trypsin at $m / z 842.50$ and 2211.10.

\subsection{Database search}

Database search with the peptide masses was performed against the Swiss-Prot database using the Peptldent search algorithm (http://www.expasy.ch/tools/peptident.html). Mass tolerance for the monoisotopic peptide masses was set to $50 \mathrm{ppm}$.

\section{Results}

Proteins were extracted from four control specimens and four PD specimens, and analyzed in parallel by 2-DE, using both Coomassie Brilliant Blue and silver staining. With silver staining $50-100 \%$ more spots could be visualized (Fig. 1). By considering all the data sets, no significant differences were found between controls and PD patients in terms of appearance, disappearance or shift of any spot, with both staining methods.

In order to investigate how the overall expression of proteins is potentially affected in PD with respect to controls, 142 spots were selected for further analysis from the Coomassie-stained gels. Only spots that were mostly expressed or better focalized were chosen. In both specimens, the amount of protein present in each spot was densitometrically measured and statistically evaluated. Table 1 (see Addendum) reports isoelectric points and molecular weights, as deduced from the gel, and statistical analysis of spot volumes, according to Wilcoxon test, for each protein. Figure 2 shows the position of the 142 spots in a Coomassie-stained gel from a control specimen.

To build a map of the proteins extracted from human SN specimens, we tried to identify by peptide mass fingerprinting the spots that had been selected for statistical analysis. Spots were excised, both from control and PD gels, and digested with trypsin. Peptide masses were

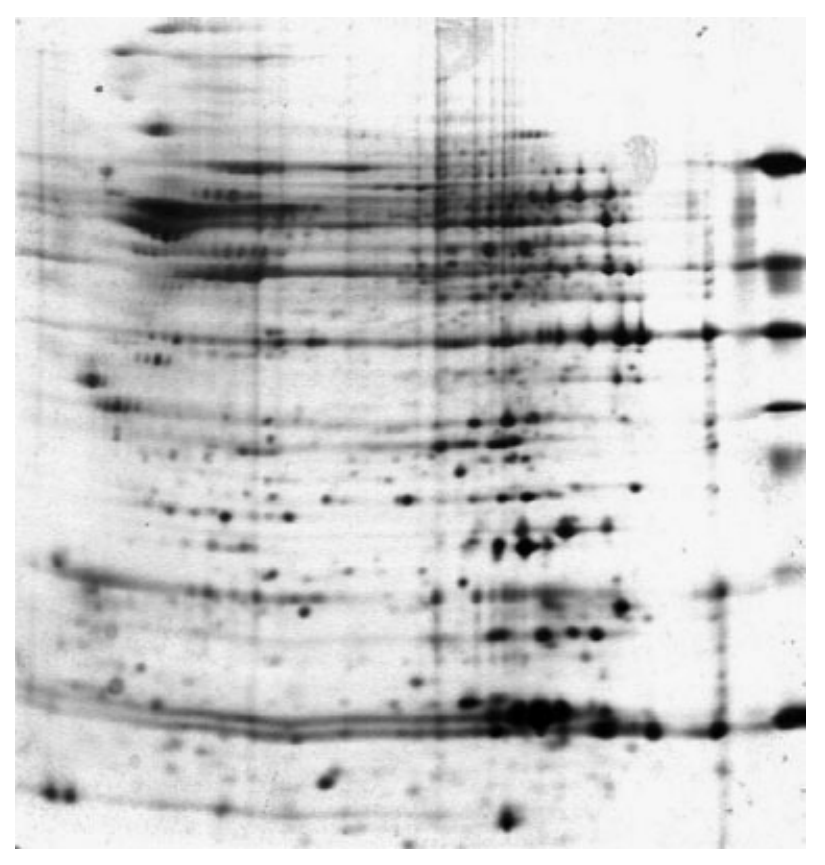

Figure 1. Silver-stained 2-DE gel of proteins extracted from an autoptic SN specimen of a control patient. 


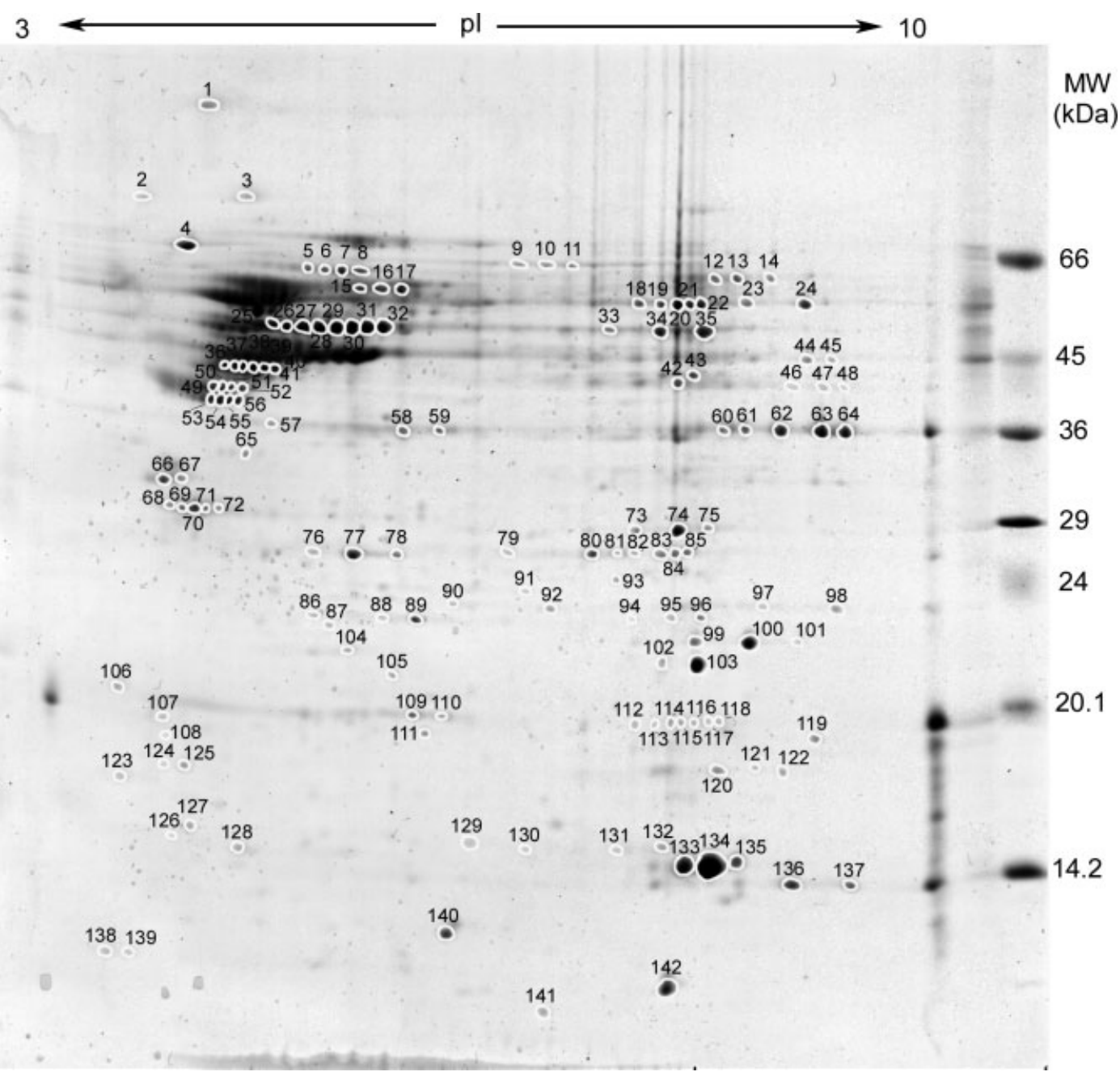

Figure 2. Coomassie-stained 2-DE gel of proteins extracted from an autoptic SN specimen of a control patient. Spots are labeled according to Table 1.

used to query the database. In order to evaluate protein identifications, we considered not only the percentage of sequence coverage (at least 20\%), as indicated in Table 1, but also the number of matching peptides (at least five) and the gap between the accepted protein and the first excluded one in the list of candidates provided by the database search (at least a difference of three peptides). The procedure was successful, and 44 proteins were identified.

As it can be noticed from Table 1 (Addendum), nine of the 44 proteins are differentially expressed in PD tissues with respect to controls $(p<0.05)$. $L$ and $M$ neurofilament chains (spots 4 and 1, respectively) are less abundant in PD specimens, which is in keeping with degeneration of SNpc neurons. The other seven proteins, namely peroxiredoxin II (spot 89), mitochondrial complex III (spots 91 and 93), ATP synthase D chain (spot 87), complexin I (spot 127), profilin (spot 129), L-type calcium channel $\delta$ - subunit (spot 123), and fatty-acid binding protein (spot 130), are significantly more expressed in PD samples than in controls.

\section{Discussion}

Proteomics is a powerful methodology to investigate how protein expression is affected in the pathogenesis of a disease process. Nevertheless, there are to date a limited number of reports in the field of neurodegenerative disorders compared to other classes of diseases [29]. One of the limits of the technique is the limited number of protein spots that can be visualized on a single gel. Only the most expressed proteins are recognized, and very large or very small proteins cannot be adequately resolved. Also the range of $\mathrm{pl}$ values is a matter of concern; although nonlinear $\mathrm{pH}$ gradients are 
commonly used, proteins having extreme $\mathrm{p} /$ values cannot focalize properly. Moreover, hydrophobic membrane proteins are difficult to resolve. Nonetheless, information on major proteins may also be of use, mainly for those proteins involved in the energetic metabolism of the cell. In a preliminary report, we observed that (mitochondrial) $\mathrm{Mn}-\mathrm{SOD}$ and dihydropteridine reductase were increased twofold in PD with respect to controls, although specimen variability did not allow to have statistically significant figures [30].

Among the 44 proteins identified in this work, nine show significant changes in their level of expression. In particular, higher expression of peroxiredoxin II is in agreement with the oxidative stress hypothesis in PD $[18,23]$. Peroxiredoxin II has been recently reported to be more expressed in the frontal cortex of PD, AD, and Down syndrome patients [31]. Peroxiredoxins are sacrificial antioxidants, i.e., instead of catalyzing ROS oxidation/ reduction they react themselves with ROS. In this process, available protein thiols (Cys-SH) are oxidized to sulfinyl residues (Cys- $\mathrm{SO}_{2}{ }^{-}$) with a consequent reduction of the $\mathrm{pl}$. To the peroxiredoxin family belongs the DJ-1 protein as well; recently, a large deletion in the DJ-1 gene was reported to cosegregate with early-onset PD in a consanguineous Dutch family; moreover, a L166P mutation was found in an Italian family [32]. DJ-1 is known to interact with c-myc and to increase cell transformation, and to inhibit the RNA-binding ability of a cAMP-responsive multiprotein complex that includes glyceraldehyde3-phosphate dehydrogenase [19]. It has also been supposed that DJ-1 acts as a ROS scavenger, thus modulating oxidant stress conditions. DJ-1 behaves as a hydroperoxide-responsive protein, that is converted into a variant with a more acidic $\mathrm{p} /$ in response to oxidative stress, suggesting a function as an antioxidant protein [33, 34]. These authors also described a similar behavior for peroxiredoxins in the case of human umbilical vein endothelial cells in response to oxidative stress [35].

Actually, there are suggestions that ROS, by-products of the oxidative metabolic pathway, may damage cell membranes through addition to unsaturated bonds in the lipid bilayer [18]. Oxidant stress conditions may, in turn, be strictly connected to excitotoxicity or to mitochondrial dysfunction [23, 36].

A reduced complex I activity was first identified in the SN of post mortem PD brain [23, 37]. Other brain areas showed normal oxidative phosphorylation activity [23, 37, 38]. Complex I defect is specific to PD and selective for the SN, but not related to the formation of LB [23]. Additional defects in complexes II and III were reported as well $[39,40]$. Mitochondrial changes in PD could either be the result from inherited mutations in the mitochondrial respiration proteins or a consequence of environmental factors and/or sporadic somatic mutations that compromise normal mitochondrial activity [23]. We report that mitochondrial complex III (ubiquinol cytochrome $c$ reductase) shows a two- to threefold increase on two independent spots, and mitochondrial complex $\mathrm{V}$ (ATP synthase) has a twofold higher abundance in PD specimens. Therefore, lower activity previously reported in the literature should be related to the inhibition of mitochondrial enzymes in PD rather than a reduction in their expression level; thus, the increased expression observed here could be related to a compensatory mechanism. In both approaches, however, it is not possible to distinguish the contribution of nigral neurons from that of glial cells in SNpc homogenates.

Complexin I, profilin, and L-type calcium channel $\delta$ subunit all appear to be more expressed in PD patients. Complexins are particularly abundant in presynaptic terminals, where they play an important role in modulating neurotransmitter release by exocytosis [41]. It has been suggested that complexin overexpression could enhance the probability of vesicle fusion upon influx of $\mathrm{Ca}^{2+}$ ions by increasing the number of vesicles close to full fusions.

It appears of peculiar interest the fact that L-type channels are more expressed in PD, as it was reported for hippocampus specimens from AD patients [42]. Increased density of L-type $\mathrm{Ca}^{2+}$ channels was actually associated to selective neuronal death in hippocampus in AD. These channels allow $\mathrm{Ca}^{2+}$ influx after a change in membrane potential due to glutamate binding to AMPA/kainate receptors. Also in $\mathrm{PD}$, the increase of calcium influx might constitute an additional risk factor for involved neurons.

Actually, most of the results described here concern presynaptic proteins; since our specimens are composed by mesencephalic SN, the findings described are probably related to modifications of afferent fibers to nigral dopaminergic neurons as a consequence of the extensive SN cell death. In this view, two possible considerations could be made: first, the increase of presynaptic proteins in afferent terminals could be a mechanism to increase dopamine release by nigrostriatal neurons; second, this possible afferent hyperactivity could also involve glutamatergic fibers from subthalamic nucleus, supporting, at least partially, the excitotoxic hypothesis for SN degeneration [43]. Concerning profilin, it is a cytoskeletoninteracting protein that binds to actin monomers resulting in cytoskeletal changes. This finding could therefore be suggestive of modifications of neurofilaments at the SNpc level that takes place during the neurodegenerative process of PD. Unlike a similar work on AD brain areas [44], cytoplasmic Cu,Zn-SOD (spot 109) and $\alpha$-crystallin B chain (spots 102 and 103) do not appear here to be pres- 
ent in increased amount in PD SN tissue with respect to the controls. Ubiquitin (spot 142) appears in all maps with comparable intensities. This aspect has to be related to the hypothesis that an impairment in UCH-L1 activity [45], that would reduce the availability of ubiquitin monomers for further ubiquitin tagging of proteins to be degraded, is a minor factor in sporadic PD [46].

In conclusion, we have identified proteomic coordinates of 44 proteins expressed in human $\mathrm{SN}$ and a comparison between controls and PD patients have been made. Our findings are consistent with the view of oxidative stress involvement in PD pathogenesis, as suggested by overexpression of mitochondrial and ROS-scavenging proteins. Moreover, our work provides information about a possible potentiation mechanism of afferent signals to SN following degeneration of dopaminergic neurons. Finally, this extensive application of the proteomic approach to understand the molecular basis of PD demonstrates the great potentiality of this methodology in the field of neurodegenerative disorders.

The authors thank Professor Riccardo Fesce for helpful discussion. We gratefully acknowledge Fondazione Cavalieri Ottolenghi, Torino, Italy and Fondazione Monzino, Milano, Italy for financial support.

\section{References}

[1] Lang, A. E., Lozano, A. M., New Engl. J. Med. 1999, 339, 1044-1053.

[2] Martin, J. B., New Engl. J. Med. 1999, 340, 1970-1980.

[3] Lewy, F. H., in: Lewandowsky, M., Abelsdorff, G. (Eds.), Handbuch der Neurologie Band III, Springer, Berlin 1912, pp. 920-933.

[4] Galvin, J. E., Lee, V. M-Y., Schmidt, L., Tu, P-H., Iwatsubo, T., Trojanowski, J. Q., Adv. Neurol. 1999, 80, 313-324.

[5] Spillantini, M. G., Schmidt, M. L., Lee, V. M., Lee, Y. et al., Nature 1997, 388, 839-840.

[6] Polymeropoulos, M. H., Lavedan, C., Leroy, E., Ide, S. E. et al., Science 1997, 276, 2045-2047.

[7] Krüger, R., Kuhn, W., Müller, T., Woitalla, D. et al., Nat. Genet. 1998, 18, 106-108.

[8] Schulz, J. B., Dichgans, J., Curr. Op. Neurol. 1999, 12, 433439.

[9] Golbe, L. I., Mov. Disord. 1999, 14, 6-9.

[10] Goedert, M., Nat. Rev. Neurosci. 2001, 2, 492-501.

[11] Narhi, L., Wood, S. J, Steavenson, S., Jiang, Y. et al., J. Biol. Chem. 1999, 274, 9843-9846.

[12] Wood, S. J., J. Biol. Chem. 1999, 274, 19509-19512.

[13] Conway, K. A., Lee, S.-J., Rochet, J.-C., Ding, T. T. et al., Proc. Natl. Acad. Sci. USA 2000, 97, 571-576.

[14] Kanda, S., Bishop, J. F., Eglitis, M. A., Yang, Y., Mouradian, M. M., Neuroscience 2000, 97, 279-284.

[15] Tabrizi, S. J., Orth, M., Wilkinson, J. M., Taanman, J. W. et al., Hum. Mol. Genet. 2000, 9, 2683-2689.

[16] Tanaka, Y., Engelender, S., Igarashi, S., Rao, R. K. et al., Hum. Mol. Genet. 2001, 10, 919-926.
[17] Junn, E., Mouradian, M. M., Neurosci. Lett. 2002, 320, 146150.

[18] Przedborski, S., Jackson-Lewis, V. R., in: Poli, G., Cadenas, E., Packer, L. (Eds.), Free Radicals in Brain Pathophysiology, Marcel Dekker, New York 2000, pp. 273-290.

[19] Cookson, M. R., Neuron 2003, 37, 7-10.

[20] Ischiropoulos, H., Beckman, J. S., J. Clin. Invest. 2003, 111, 163-169.

[21] Jenner, P., Ann. Neurol. 2003, 53 Suppl. 3, S26-S36.

[22] Finkel, T., Holbrook, N. J., Nature 2000, 408, 239-247.

[23] Orth, M., Schapira, A. H., Neurochem. Int. 2002, 40, 533541.

[24] Borden, K. L., Ann. Neurol. 1998, 44, S65-S71.

[25] Lopiano, L., Fasano, M., Giraudo, S., Digilio, G. et al., Neurochem. Int. 2000, 37, 331-336.

[26] Lotharius, J., Brundin, P., Hum. Mol. Genet. 2002, 11, 23952407.

[27] Jacobs, D. I., van Rijssen, M. S., van der Heijden, R., Verpoorte, R., Proteomics 2001, 1, 1345-1350.

[28] Sinha, P., Poland, J., Schnölzer, M., Rabilloud, T., Proteomics 2001, 1, 835-840.

[29] Morrison, R. S., Kinoshita, Y., Johnson, M. D., Uo, T. et al., Mol. Cell. Proteomics 2002, 1, 553-560.

[30] Basso, M., Giraudo, S., Lopiano, L., Bergamasco, B. et al., Neurol. Sci. 2003, 24, 155-156.

[31] Krapfenbauer, K., Engidawork, E., Cairns, N., Fountoulakis, M., Lubec, G., Brain Res. 2003, 967, 152-160.

[32] Bonifati, V., Rizzu, P., van Baren, M. J., Schaap, O. et al., Science 2002, 199, 256-259.

[33] Mitsumoto, A., Nakagawa, Y., Takeuchi, A., Okawa, K. et al., Free Radic. Res. 2001, 35, 301-310.

[34] Mitsumoto, A., Nakagawa, Y., Free Radic. Res. 2001, 35, 885-893.

[35] Mitsumoto, A., Takanezawa, Y., Okawa, K., Iwamatsu, A., Nakagawa, Y., Free Radic. Biol. Med. 2001, 30, 625-635.

[36] Pocernich, C. B., Cardin, A. L., Racine, C. L., Lauderback, C. M., Butterfield, D. A., Neurochem. Int. 2001, 39, 141-149.

[37] Gu, M., Owen, A. D., Toffa, S. E. K., Cooper, J. M. et al., J. Neurol. Sci. 1998, 158, 24-29.

[38] Cooper, J. M., Daniel, S. E., Marsden, C. D., Schapira, A. H. V., Mov. Disord. 1995, 10, 295-297.

[39] Mizuno, Y., Suzuki, K., Ohta, S., J. Neurol. Sci. 1990, 96, 4957.

[40] Mizuno, Y., Matuda, S., Yoshino, H., Moro, H. et al., Ann. Neurol. 1994, 35, 201-210.

[41] Marz, K. E., Hanson, P. I., Trends Neurosci. 2002, 25, 381383.

[42] Coon, A. L., Wallace, D. R., Mactutus, C. F., Booze, R. M., Neurobiol. Aging 1999, 20, 597-603.

[43] Gu, B., Zhang, Y. D., Hu, G., Neurosci. Lett. 2003, 351, 186190.

[44] Schonberger, S. J., Edgar, P. F., Kydd, R., Faull, R. L. M., Cooper, G. J. S., Proteomics 2001, 1, 1519-1528.

[45] Leroy, E., Boyer, R., Auburger, G., Leube, B. et al., Nature 1998, 395, 451-452.

[46] Harhangi, B. S., Farrer, M. J., Lincoln, S., Bonifati, V. et al., Neurosci. Lett. 1999, 270, 1-4. 


\section{Addendum}

Table 1. Statistical analysis and identification of proteins from human SN of control subjects and PD patients

\begin{tabular}{|c|c|c|c|c|c|c|c|c|c|c|}
\hline Spot & Controls (\%) & PD (\%) & $\begin{array}{l}\text { Calcul- } \\
\text { ated pl }\end{array}$ & $\begin{array}{l}\text { Calculated } \\
\text { MW (kDa) }\end{array}$ & $\begin{array}{l}p \\
\text { Wilcoxon }\end{array}$ & Protein & $\begin{array}{l}\text { Theoreti- } \\
\text { cal pl }\end{array}$ & $\begin{array}{l}\text { Theoreti- } \\
\text { cal MW } \\
(\mathrm{kDa})\end{array}$ & ID & $\begin{array}{l}\% \text { Seq. } \\
\text { covered }\end{array}$ \\
\hline 1 & $6.632 \pm 5.188$ & $1.629 \pm 1.410$ & 4.462 & $\begin{array}{l}119637 \\
64446.37\end{array}$ & 0.002 & Neurofilament M & 4.90 & 102316 & P07197 & 28.6 \\
\hline 2 & $1.365 \pm 1.974$ & $0.525 \pm 0.483$ & 4.245 & 83313 & 0.331 & & & & & \\
\hline 3 & $1.060 \pm 0.856$ & $0.775 \pm 0.552$ & 4.746 & 83313 & 0.574 & & & & & \\
\hline 4 & $6.867 \pm 3.386$ & $3.075 \pm 1.741$ & 4.462 & 69118 & 0.001 & Neurofilament L & 4.66 & 61646 & P07196 & 43.6 \\
\hline 5 & $0.285 \pm 0.129$ & $0.258 \pm 0.158$ & 5.050 & 63521 & 0.689 & & & & & \\
\hline 6 & $0.380 \pm 0.215$ & $0.420 \pm 0.387$ & 5.150 & 63249 & 0.456 & & & & & \\
\hline 7 & $0.378 \pm 0.126$ & $0.317 \pm 0.126$ & 5.222 & 62979 & 0.438 & & & & & \\
\hline 8 & $0.263 \pm 0.109$ & $0.195 \pm 0.074$ & 5.291 & 62844 & 0.252 & & & & & \\
\hline 9 & $0.186 \pm 0.103$ & $0.251 \pm 0.121$ & 6.186 & 64623 & 0.867 & Serum albumin & 5.67 & 66472 & P02768 & 21.4 \\
\hline 10 & $0.231 \pm 0.141$ & $0.345 \pm 0.110$ & 5.351 & 64345 & 0.613 & & & & & \\
\hline 11 & $0.159 \pm 0.170$ & $0.414 \pm 0.226$ & 6.514 & 64207 & 0.152 & & & & & \\
\hline 12 & $0.371 \pm 0.520$ & $0.290 \pm 0.186$ & 7.386 & 61125 & 0.645 & & 7.95 & 57783 & P14786 & 33.4 \\
\hline 13 & $0.495 \pm 0.329$ & $0.547 \pm 0.282$ & 7.534 & 61125 & 0.721 & Pyruvate KInase, & & & & \\
\hline 14 & $0.328 \pm 0.264$ & $0.407 \pm 0.206$ & 7.780 & 61386 & 0.235 & & & & & \\
\hline 15 & $0.250 \pm 0.149$ & $0.184 \pm 0.058$ & 5.310 & 59088 & 0.388 & & & & & \\
\hline 16 & $0.279 \pm 0.201$ & $0.398 \pm 0.172$ & 5.406 & 58840 & 0.541 & & & & & \\
\hline 17 & $0.211 \pm 0.084$ & $0.382 \pm 0.151$ & 5.499 & 58716 & 0.167 & & & & & \\
\hline 18 & $0.371 \pm 0.486$ & $0.465 \pm 0.185$ & 6.924 & 55956 & 1.427 & & 6.71 & 56009 & P00367 & 21 \\
\hline 19 & $0.447 \pm 0.293$ & $0.345 \pm 0.139$ & 7.049 & 55840 & 1.257 & & & & & \\
\hline 20 & $0.286 \pm 0.076$ & $0.353 \pm 0.219$ & 7.157 & 55493 & 0.837 & Glu dehydrogenase 1, & & & & \\
\hline 21 & $0.341 \pm 0.216$ & $0.246 \pm 0.150$ & 7.224 & 55608 & 0.955 & mitochondrial & & & & \\
\hline 22 & $0.388 \pm 0.158$ & $0.390 \pm 0.169$ & 7.295 & 55608 & 1.242 & & & & & \\
\hline 23 & $0.491 \pm 0.193$ & $0.562 \pm 0.214$ & 7.591 & 56073 & 0.808 & & & & & \\
\hline 24 & $1.444 \pm 1.157$ & $1.270 \pm 0.651$ & 8.022 & 56073 & 1.269 & $\begin{array}{l}\text { ATP synthase } \alpha \text {-chain, } \\
\text { mitochondrial }\end{array}$ & 8.28 & 55209 & P25705 & 32.9 \\
\hline 25 & $0.121 \pm 0.091$ & $0.172 \pm 0.107$ & 5.027 & 51747 & 0.643 & & 5.42 & 49880 & P14136 & 56.9 \\
\hline 26 & $0.282 \pm 0.185$ & $0.310 \pm 0.306$ & 5.127 & 51432 & 1.164 & & & & & \\
\hline 27 & $0.398 \pm 0.277$ & $0.557 \pm 0.375$ & 5.029 & 51016 & 0.613 & & & & & \\
\hline 28 & $0.677 \pm 0.399$ & $0.511 \pm 0.391$ & 5.291 & 51224 & 0.963 & Glial fibrillary acidic & & & & \\
\hline 29 & $1.199 \pm 0.591$ & $0.845 \pm 0.574$ & 5.393 & 51224 & 0.114 & protein, astrocyte & & & & \\
\hline 30 & $1.521 \pm 0.736$ & $0.930 \pm 0.611$ & 5.493 & 51224 & 0.077 & & & & & \\
\hline 31 & $1.319 \pm 1.016$ & $0.694 \pm 0.393$ & 5.583 & 51224 & 0.222 & & & & & \\
\hline 32 & $0.936 \pm 0.747$ & $0.589 \pm 0.541$ & 5.590 & 51224 & 0.423 & & & & & \\
\hline 33 & $0.750 \pm 0.527$ & $0.698 \pm 0.390$ & 6.734 & 50913 & 1.175 & & & & & \\
\hline 34 & $1.782 \pm 0.547$ & $1.904 \pm 0.740$ & 7.034 & 50605 & 0.758 & & & & & \\
\hline 35 & $1.229 \pm 0.500$ & $1.908 \pm 0.779$ & 7.036 & 50503 & 0.114 & & & & & \\
\hline 36 & $0.103 \pm 0.059$ & $0.069 \pm 0.033$ & 4.668 & 45013 & 0.412 & & & & & \\
\hline 37 & $0.154 \pm 0.090$ & $0.101 \pm 0.007$ & 4.718 & 44838 & 0.230 & & & & & \\
\hline 38 & $0.271 \pm 0.188$ & $0.123 \pm 0.022$ & 4.762 & 44925 & 0.073 & & & & & \\
\hline 39 & $0.271 \pm 0.103$ & $0.162 \pm 0.057$ & 4.810 & 44838 & 0.073 & & & & & \\
\hline 40 & $0.280 \pm 0.113$ & $0.192 \pm 0.059$ & 4.854 & 44664 & 0.164 & & & & & \\
\hline 41 & $0.315 \pm 0.146$ & $0.176 \pm 0.044$ & 4.908 & 44491 & 0.257 & & & & & \\
\hline 42 & $0.204 \pm 0.097$ & $0.298 \pm 0.183$ & 7.190 & 42404 & 0.354 & $\begin{array}{l}\text { Fructose-bisphosphate } \\
\text { aldolase C }\end{array}$ & 6.46 & 39325 & P09972 & 36.1 \\
\hline 43 & $0.253 \pm 0.156$ & $0.421 \pm 0.193$ & 7.261 & 43640 & 0.222 & $\begin{array}{l}\text { Aspartate aminotransferase, } \\
\text { cytoplasmic }\end{array}$ & 6.57 & 46116 & P17174 & 38.1 \\
\hline
\end{tabular}


Table 1. Continued

\begin{tabular}{|c|c|c|c|c|c|c|c|c|c|c|}
\hline Spot & Controls (\%) & PD (\%) & $\begin{array}{l}\text { Calcul- } \\
\text { ated } \mathrm{pl}\end{array}$ & $\begin{array}{l}\text { Calculated } \\
\text { MW (kDa) }\end{array}$ & $\begin{array}{l}p \\
\text { Wilcoxon }\end{array}$ & Protein & $\begin{array}{l}\text { Theoreti- } \\
\text { cal pl }\end{array}$ & $\begin{array}{l}\text { Theoreti- } \\
\text { cal MW } \\
(\mathrm{kDa})\end{array}$ & ID & $\begin{array}{l}\% \text { Seq. } \\
\text { covered }\end{array}$ \\
\hline $\begin{array}{l}44 \\
45\end{array}$ & $\begin{array}{l}0.495 \pm 0.288 \\
0.221 \pm 0.194\end{array}$ & $\begin{array}{l}0.605 \pm 0.247 \\
0.453 \pm 0.239\end{array}$ & $\begin{array}{l}8.033 \\
8.219\end{array}$ & $\begin{array}{l}46081 \\
45991\end{array}$ & $\begin{array}{l}0.435 \\
0.065\end{array}$ & Phosphoglycerate kinase 1 & 8.30 & 44597 & P00558 & 20.01 \\
\hline 46 & $0.136 \pm 0.058$ & $0.185 \pm 0.092$ & 7.935 & 42163 & 0.435 & & & & & \\
\hline 47 & $0.218 \pm 0.083$ & $0.268 \pm 0.142$ & 8.124 & 41844 & 0.524 & & & & & \\
\hline 48 & $0.111 \pm 0.051$ & $0.169 \pm 0.094$ & 8.271 & 41765 & 0.435 & & & & & \\
\hline 49 & $0.084 \pm 0.031$ & $0.075 \pm 0.049$ & 4.605 & 41844 & 0.442 & & & & & \\
\hline 50 & $0.154 \pm 0.090$ & $0.093 \pm 0.068$ & 4.652 & 41765 & 0.235 & & & & & \\
\hline 51 & $0.228 \pm 0.127$ & $0.141 \pm 0.128$ & 4.696 & 41686 & 0.161 & & & & & \\
\hline 52 & $0.218 \pm 0.088$ & $0.177 \pm 0.164$ & 4.746 & 41607 & 0.645 & & & & & \\
\hline 53 & $0.258 \pm 0.097$ & $0.168 \pm 0.114$ & 4.599 & 40225 & 0.108 & & & & & \\
\hline 54 & $0.301 \pm 0.094$ & $0.212 \pm 0.124$ & 4.643 & 40075 & 0.154 & & & & & \\
\hline 55 & $0.499 \pm 0.163$ & $0.321 \pm 0.233$ & 4.683 & 40000 & 0.277 & & & & & \\
\hline 56 & $0.274 \pm 0.290$ & $0.475 \pm 0.289$ & 4.734 & 40075 & 0.148 & & & & & \\
\hline 57 & $0.146 \pm 0.085$ & $0.169 \pm 0.115$ & 4.886 & 37376 & 0.762 & & & & & \\
\hline 58 & $0.148 \pm 0.118$ & $0.321 \pm 0.126$ & 5.493 & 36513 & 0.073 & $\begin{array}{l}\text { Guanine nucleotide-binding } \\
\text { protein } \beta \text {-subunit } 1\end{array}$ & 5.60 & 37377 & P04901 & 27.6 \\
\hline 59 & $0.255 \pm 0.165$ & $0.509 \pm 0.258$ & 5.731 & 36513 & 0.053 & & & & & \\
\hline 60 & $0.343 \pm 0.297$ & $0.268 \pm 0.095$ & 7.450 & 36775 & 0.860 & Glyceraldehyde 3-phosphate & 8.58 & 35922 & P04406 & 30.5 \\
\hline 61 & $0.665 \pm 0.384$ & $0.548 \pm 0.261$ & 7.610 & 36775 & 0.596 & dehydrogenase & & & & \\
\hline 62 & $1.146 \pm 0.511$ & $1.048 \pm 0.764$ & 7.865 & 36578 & 0.331 & & & & & \\
\hline 63 & $1.810 \pm 0.580$ & $1.770 \pm 1.254$ & 8.140 & 36448 & 0.377 & & & & & \\
\hline 64 & $1.479 \pm 0.474$ & $1.518 \pm 0.712$ & 8.327 & 36318 & 0.724 & & & & & \\
\hline 65 & $0.253 \pm 0.180$ & $0.354 \pm 0.152$ & 4.772 & 33976 & 0.345 & & & & & \\
\hline 66 & $0.290 \pm 0.161$ & $0.495 \pm 0.276$ & 4.385 & 31699 & 0.161 & 14-3-3 protein $\varepsilon$ & 4.67 & 29174 & P42655 & 65.9 \\
\hline 67 & $0.323 \pm 0.314$ & $0.295 \pm 0.276$ & 4.485 & 31646 & 1.269 & & & & & \\
\hline 68 & $0.136 \pm 0.128$ & $0.115 \pm 0.072$ & 4.486 & 29327 & 1.245 & 14-3-3 protein $\gamma$ & 4.80 & 28171 & P35214 & 44.7 \\
\hline 69 & $0.234 \pm 0.191$ & $0.251 \pm 0.093$ & 4.531 & 29096 & 0.383 & & & & & \\
\hline 70 & $0.294 \pm 0.179$ & $0.422 \pm 0.251$ & 4.533 & 29188 & 0.336 & & & & & \\
\hline 71 & $0.180 \pm 0.081$ & $0.272 \pm 0.141$ & 4.589 & 29096 & 0.272 & & & & & \\
\hline 72 & $0.119 \pm 0.164$ & $0.167 \pm 0.152$ & 4.655 & 29142 & 0.083 & & & & & \\
\hline 73 & $0.445 \pm 0.239$ & $0.557 \pm 0.363$ & 6.916 & 27566 & 0.860 & Phosphoglycerate mutase 1 & 6.75 & 28672 & P18669 & 38.3 \\
\hline 74 & $2.247 \pm 0.841$ & $1.755 \pm 0.581$ & 7.183 & 27525 & 0.190 & & & & & \\
\hline 75 & $0.648 \pm 0.116$ & $0.461 \pm 0.176$ & 7.378 & 27650 & 0.024 & & & & & \\
\hline 76 & $0.378 \pm 0.561$ & $0.399 \pm 0.307$ & 5.144 & 26057 & 1.530 & & & & & \\
\hline 77 & $1.346 \pm 0.810$ & $1.763 \pm 0.663$ & 5.291 & 25869 & 0.222 & Ubiquitin thiolesterase L1 & 5.33 & 24824 & P09936 & 43 \\
\hline 78 & $0.604 \pm 0.702$ & $0.663 \pm 0.462$ & 5.373 & 25795 & 0.222 & & & & & \\
\hline 79 & $0.274 \pm 0.431$ & $0.191 \pm 0.082$ & 6.140 & 26019 & 0.366 & & & & & \\
\hline 80 & $1.187 \pm 0.739$ & $1.436 \pm 0.674$ & 6.665 & 25944 & 0.480 & Dihydropteridine reductase & 6.90 & 25.803 & P09417 & 55.3 \\
\hline 81 & $0.371 \pm 0.240$ & $0.318 \pm 0.112$ & 6.810 & 25982 & 0.798 & & & & & \\
\hline 82 & $0.219 \pm 0.126$ & $0.181 \pm 0.060$ & 6.920 & 25982 & 0.681 & & & & & \\
\hline 83 & $0.354 \pm 0.287$ & $0.552 \pm 0.293$ & 7.079 & 25869 & 0.162 & & & & & \\
\hline 84 & $0.358 \pm 0.214$ & $0.258 \pm 0.114$ & 7.187 & 25869 & 0.673 & & & & & \\
\hline 85 & $0.641 \pm 0.334$ & $0.562 \pm 0.219$ & 7.269 & 25944 & 0.724 & & & & & \\
\hline 86 & $0.132 \pm 0.085$ & $0.184 \pm 0.078$ & 5.144 & 21759 & 1.242 & & & & & \\
\hline 87 & $0.132 \pm 0.100$ & $0.232 \pm 0.116$ & 5.160 & 20391 & 0.050 & $\begin{array}{l}\text { ATP synthase D chain, } \\
\text { mitochondrial }\end{array}$ & 5.22 & 18360 & 075947 & 63.7 \\
\hline 88 & $0.426 \pm 0.766$ & $0.284 \pm 0.112$ & 5.439 & 21685 & 1.059 & & & & & \\
\hline 89 & $0.800 \pm 0.330$ & $1.596 \pm 0.496$ & 5.573 & 21661 & 0.004 & Peroxiredoxin 2 & 5.66 & 21891 & P32119 & 42.9 \\
\hline 90 & $0.205 \pm 0.223$ & $0.271 \pm 0.148$ & 5.830 & 22419 & 0.299 & & & & & \\
\hline
\end{tabular}


Table 1. Continued

\begin{tabular}{|c|c|c|c|c|c|c|c|c|c|c|}
\hline Spot & Controls (\%) & PD (\%) & $\begin{array}{l}\text { Calcul- } \\
\text { ated pl }\end{array}$ & $\begin{array}{l}\text { Calculated } \\
\text { MW (kDa) }\end{array}$ & $\begin{array}{l}p \\
\text { Wilcoxon }\end{array}$ & Protein & $\begin{array}{l}\text { Theoreti- } \\
\text { cal pl }\end{array}$ & $\begin{array}{l}\text { Theoreti- } \\
\text { cal MW } \\
(\mathrm{kDa})\end{array}$ & ID & $\begin{array}{l}\% \text { Seq. } \\
\text { covered }\end{array}$ \\
\hline 91 & $0.073 \pm 0.094$ & $0.118 \pm 0.029$ & 6.277 & 23210 & 0.043 & $\begin{array}{l}\text { Ubiquinol-cytochrome } c \\
\text { reductase iron-sulfur } \\
\text { subunit, mitochondrial }\end{array}$ & 6.30 & 21616 & P47985 & 23.5 \\
\hline 92 & $0.327 \pm 0.240$ & $0.428 \pm 0.155$ & 6.415 & 22527 & 0.272 & & & & & \\
\hline 93 & $0.152 \pm 0.058$ & $0.454 \pm 0.125$ & 6.803 & 24387 & 0.003 & $\begin{array}{l}\text { Ubiquinol-cytochrome } c \\
\text { reductase iron-sulfur } \\
\text { subunit, mitochondrial }\end{array}$ & 6.30 & 21616 & P47985 & 25 \\
\hline 94 & $0.120 \pm 0.141$ & $0.153 \pm 0.168$ & 6.924 & 22084 & 0.731 & Superoxide dismutase [Mn] & 6.86 & 22204 & P04179 & 21.7 \\
\hline 95 & $0.300 \pm 0.170$ & $0.300 \pm 0.172$ & 7.149 & 22135 & 1.000 & & & & & \\
\hline 96 & $0.515 \pm 0.303$ & $0.752 \pm 0.285$ & 7.348 & 22160 & 0.077 & & & & & \\
\hline 97 & $0.161 \pm 0.077$ & $0.352 \pm 0.107$ & 7.753 & 22912 & 0.121 & & & & & \\
\hline 98 & $0.604 \pm 0.341$ & $0.941 \pm 0.453$ & 8.283 & 22605 & 0.181 & Peroxiredoxin 1 & 8.27 & 22110 & Q06830 & 37.2 \\
\hline $\begin{array}{r}99 \\
100\end{array}$ & $\begin{array}{l}1.120 \pm 0.576 \\
3.777 \pm 0.971\end{array}$ & $\begin{array}{l}1.075 \pm 0.566 \\
3.535 \pm 0.691\end{array}$ & $\begin{array}{l}7.299 \\
7.675\end{array}$ & $\begin{array}{l}21303 \\
21140\end{array}$ & $\begin{array}{l}0.596 \\
0.930\end{array}$ & $\alpha$-crystallin B chain & 6.76 & 20159 & 043416 & 35.6 \\
\hline 101 & $0.306 \pm 0.166$ & $0.292 \pm 0.262$ & 8.025 & 21256 & 1.530 & $\begin{array}{l}\text { Phosphatidylethanolamine- } \\
\text { binding protein }\end{array}$ & 7.43 & 20925 & P30086 & 55.4 \\
\hline 102 & $1.135 \pm 0.680$ & $0.926 \pm 0.795$ & 7.123 & 20455 & 0.251 & $\alpha$-crystallin B chain & 6.76 & 20159 & P02511 & 34.3 \\
\hline 103 & $6.636 \pm 1.345$ & $6.027 \pm 1.745$ & 7.325 & 20295 & 0.480 & & & & & \\
\hline 104 & $0.211 \pm 0.118$ & $0.511 \pm 0.262$ & 5.160 & 20391 & 0.114 & Ferritin heavy chain & 5.30 & 21.907 & P02794 & 36.9 \\
\hline 105 & $0.313 \pm 0.294$ & $0.771 \pm 0.729$ & 5.410 & 19513 & 1.464 & & & & & \\
\hline 106 & $0.336 \pm 0.213$ & $0.372 \pm 0.247$ & 4.181 & 19498 & 0.943 & & & & & \\
\hline 107 & $0.046 \pm 0.031$ & $0.111 \pm 0.081$ & 4.422 & 18465 & 0.147 & & & & & \\
\hline 108 & $0.146 \pm 0.086$ & $0.068 \pm 0.054$ & 4.437 & 17951 & 0.111 & & & & & \\
\hline 109 & $0.477 \pm 0.341$ & $0.585 \pm 0.208$ & 5.596 & 18210 & 0.289 & $\begin{array}{l}\text { Superoxide dismutase } \\
\text { [Cu-Zn] }\end{array}$ & 5.70 & 15804 & P00441 & 49 \\
\hline 110 & $1.032 \pm 0.659$ & $1.369 \pm 0.682$ & 5.752 & 18241 & 0.480 & & & & & \\
\hline 111 & $0.418 \pm 0.197$ & $0.409 \pm 0.149$ & 5.508 & 18034 & 0.959 & Stathmin & 5.77 & 17171 & P16949 & 37.8 \\
\hline 112 & $0.107 \pm 0.087$ & $0.340 \pm 0.107$ & 6.633 & 18272 & 0.200 & Myelin basic protein & 6.00 & 21522 & $\begin{array}{l}\text { P02686- } \\
2 \text { (iso- } \\
\text { form) }\end{array}$ & 24.4 \\
\hline 113 & $0.037 \pm 0.025$ & $0.227 \pm 0.169$ & 6.693 & 18324 & 0.095 & & & & & \\
\hline 114 & $0.088 \pm 0.090$ & $0.271 \pm 0.139$ & 6.799 & 18376 & 0.143 & & & & & \\
\hline 115 & $0.084 \pm 0.098$ & $0.209 \pm 0.092$ & 6.946 & 18359 & 0.381 & & & & & \\
\hline 116 & $0.055 \pm 0.057$ & $0.157 \pm 0.092$ & 7.068 & 18341 & 0.229 & & & & & \\
\hline 117 & $0.335 \pm 0.363$ & $0.185 \pm 0.030$ & 7.172 & 18324 & 1.600 & & & & & \\
\hline 118 & $0.042 \pm 0.010$ & 0.191667 & 7.254 & 18376 & 2.000 & & & & & \\
\hline 119 & $0.577 \pm 0.497$ & $0.848 \pm 0.529$ & 8.160 & 17870 & 0.351 & Cofilin, non-muscle isoform & 8.22 & 18502 & P23528 & 47 \\
\hline 120 & $0.512 \pm 0.287$ & $0.815 \pm 0.422$ & 7.469 & 17024 & 0.162 & $\begin{array}{l}\text { Peptidyl-prolyl cis-trans } \\
\text { isomerase A }\end{array}$ & 7.82 & 17881 & P05092 & 34.1 \\
\hline 121 & $0.299 \pm 0.399$ & $0.300 \pm 0.147$ & 7.749 & 17066 & 0.606 & & & & & \\
\hline 122 & $0.304 \pm 0.261$ & $0.557 \pm 0.389$ & 7.943 & 16996 & 0.077 & & & & & \\
\hline 123 & $0.141 \pm 0.081$ & $0.377 \pm 0.214$ & 4.202 & 16591 & 0.008 & $\begin{array}{l}\text { Chain 2: L-type calcium } \\
\text { channel } \delta \text {-subunit }\end{array}$ & 4.47 & 16466 & P54289 & 36.7 \\
\hline 124 & $0.060 \pm 0.038$ & $0.148 \pm 0.091$ & 4.431 & 16850 & 0.065 & Chain 1: factor $\mathrm{X}$ light chain & 4.59 & 15725 & P00742 & 53.2 \\
\hline 125 & $0.591 \pm 0.398$ & $0.807 \pm 0.384$ & 4.527 & 16838 & 0.232 & & & & & \\
\hline 126 & $0.132 \pm 0.219$ & $0.066 \pm 0.054$ & 4.462 & 15654 & 0.876 & $\begin{array}{l}\text { Cytochrome c oxidase poly- } \\
\text { peptide Va, mitochondrial }\end{array}$ & 4.88 & 12513 & P20674 & 36.7 \\
\hline 127 & $0.093 \pm 0.024$ & $0.277 \pm 0.152$ & 4.540 & 15835 & 0.008 & Complexin 1 & 4.93 & 15030 & 014810 & 36.6 \\
\hline 128 & $0.239 \pm 0.140$ & $0.431 \pm 0.111$ & 4.769 & 15442 & 0.189 & Galectin-1 & 5.34 & 14584 & P09382 & 60.4 \\
\hline
\end{tabular}


Table 1. Continued

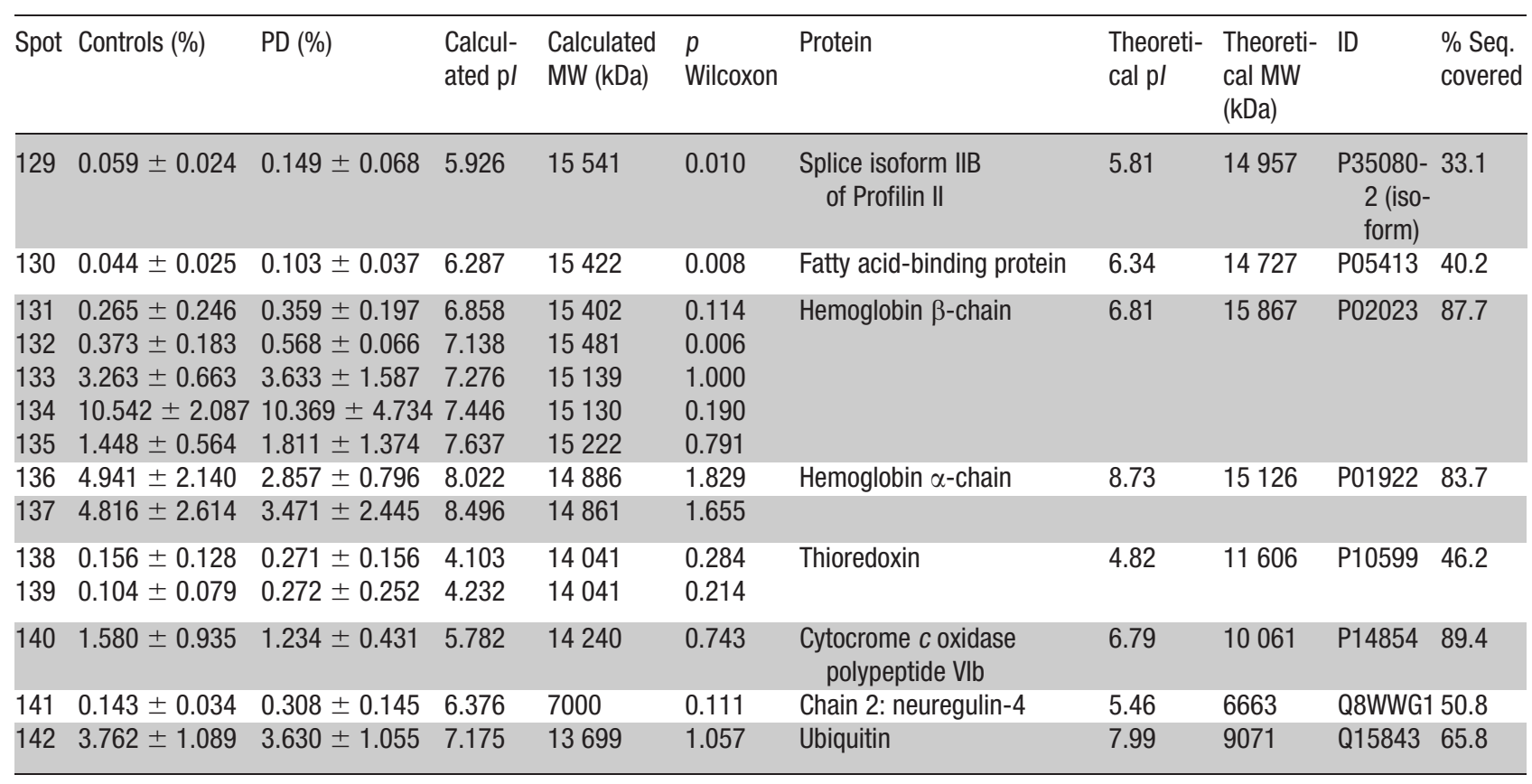

